Article

\title{
Circular Economy Approach on Energy Cogeneration in Petroleum Refining
}

\author{
Luiz Fernando Rodrigues Pinto ${ }^{1, *} \mathbb{( \mathbb { D }}$, Henrricco Nieves Pujol Tucci ${ }^{1}$, Giovanni Mummolo ${ }^{2, *}$, \\ Geraldo Cardoso de Oliveira Neto ${ }^{1}\left[{ }^{1}\right.$ and Francesco Facchini ${ }^{3}$ (i)
}

check for

updates

Citation: Pinto, L.F.R.; Tucci, H.N.P.; Mummolo, G.; Neto, G.C.d.O.; Facchini, F. Circular Economy Approach on Energy Cogeneration in Petroleum Refining. Energies 2022, 15, 1713. https://doi.org/10.3390/ en15051713

Academic Editors: Mark Laser and Antonis A. Zorpas

Received: 28 January 2022

Accepted: 23 February 2022

Published: 25 February 2022

Publisher's Note: MDPI stays neutral with regard to jurisdictional claims in published maps and institutional affiliations.

Copyright: (C) 2022 by the authors. Licensee MDPI, Basel, Switzerland. This article is an open access article distributed under the terms and conditions of the Creative Commons Attribution (CC BY) license (https:// creativecommons.org/licenses/by/ $4.0 /)$
1 Industrial Engineering Post-Graduation Program, Universidade Nove de Julho (UNINOVE), Liberdade 01504-001, Brazil; henrricco@gmail.com (H.N.P.T.); geraldo.prod@gmail.com (G.C.d.O.N.)

2 Ionic Department in Legal and Economic System of Mediterranean: Society, Environment, Culture, Università Degli Studi Di Bari Aldo Moro, 74100 Taranto, Italy

3 Department of Mechanics, Mathematics and Management, Polytechnic University of Bari, 70125 Bari, Italy; francesco.facchini@poliba.it

* Correspondence: Ifernandorp44@gmail.com (L.F.R.P.); giovanni.mummolo@uniba.it (G.M.)

\begin{abstract}
The heat recovery of hot exhaust air in petroleum refining for energy cogeneration is a circular strategy to reduce costs and environmental impact. Despite several articles on this subject, there is a lack of study on the assessment of the economic and environmental advantages of energy cogeneration in petroleum refining. The objective of this research was to evaluate the economic and environmental gains obtained by energy cogeneration from the heat dissipated in the calcination of green petroleum coke. The research method was a case study in a petrochemical industry in Brazil. From an economic point of view, the cogeneration unit project has shown positive results: a discounted payback period of eight years and nine months, net present value (NPV) over a span of a twenty-year period of US\$43,825,592, a return on investment (ROI) estimated to be $14 \%$, and an internal rate of return (IRR) of $12 \%$. From an ecological perspective, the produced energy in the cogeneration process reduced 163,992 ton $\mathrm{CO}_{2}$ eq per year of greenhouse gas emissions into the atmosphere. This study has increased the knowledge of heat recovery in energy cogeneration in petroleum refining. This work contributes by providing some advantages of heat recovery as a circular economy strategy for business development.
\end{abstract}

Keywords: circular economy; cogeneration; heat recovery; greenhouse gas emission; carbon emission reduction

\section{Introduction}

Power cogeneration is an alternative that has been employed by companies to promote the circular economy [1,2]. The use of materials for cogeneration improves energy efficiency, resource circularity and reduces environmental impact [3]. The valorization of waste biomass through cogeneration currently plays a significant role in the circular economy, in which waste must be reused to the maximum extent possible [1,2]. The sustainable use and recycling of secondary raw materials are the backbone of the circular economy, which aims to minimize environmental impact through the efficient conversion of resources and energy [4].

The purpose of a circular economy is to minimize the energy and material wastes by turning them into resources for other purposes in a closed loop system [5]. Circular economy strategies could potentially reduce life cycle greenhouse gas emissions and resource consumption by increasing renewable energy and recycled materials [6]. The circular economy activities, such as increasing resources use efficiency by achieving a closed loop, has the potential of mitigating greenhouse gas emission [7]. Themes of reducing carbon emissions, promoting sustainable entrepreneurial ecosystem, and the circular economy are aligned to the Paris agreement for climate change [8]. 
The petroleum refining industry is an important energy conversion sector that supplies products and raw materials to several sectors, including the chemical industry and transportation [9]. Despite its relevance in providing resources for industrial activity, petroleum refining causes several damages to the environment, most notably high $\mathrm{CO}_{2}$ emissions [10]. In the life cycle of production and petroleum products use, which includes crude petroleum extraction, transportation, refining, and fuel combustion, more than $40 \%$ of environmental impacts are attributed to the petroleum refining stage [11]. Still, environmental analysis of petroleum refining is limited [12]. One option to mitigate greenhouse gas emissions is to capture $\mathrm{CO}_{2}$ by combusting petroleum coke, which is a byproduct of petroleum refining, for power generation [13]. The industrial excess heat could be used to form symbiosis between factories [14].

The search for studies in the literature on energy cogeneration and circular economy identified articles that addressed this theme. The literature search returned exploratory research through case studies, experiments, and simulation. Some works had a qualitative approach to the economic and environmental factors. Recycling secondary raw materials contributed to the circular economy in energy cogeneration. Investment in energy cogeneration processes reduced pollutant gas emissions and was a key success factor in German poultry farming [4]. Increased revenue gained by using waste for energy production and sustainable building products was highlighted in the Indian sugarcane sector [15]. Cogeneration from straw residues contributed to the anaerobic digestion of organic feedstocks, which enabled the production of renewable methanol and increased economic gains in German agriculture [16].

Other studies focused on qualitative environmental evidence of a circular economy in energy cogeneration. The implementation of industrial eco-parks in France promoted industrial symbiosis, which resulted in environmental gain from the exchange of by-products and energy [17]. The construction of new thermochemical plants, the modernization of existing units, and the use of value-added by-products for energy production has fostered the circular economy in Italy [18]. The use of dry waste from the energy industry for biofuel production has contributed to the circular economy transition in Italy [19].

Studies carried out a qualitative approach on the economic aspect and quantitative analysis of the environmental factor. The use of simulation in Italian plants mentioned economic feasibility of recovering a wide range of wastes for biomethane production, which leveraged circular economy [20]. Biogas cogeneration using high-temperature solid oxide fuel cells in the Italian agricultural/livestock sector reduced energy consumption from $0.387 \mathrm{kWh}$ to $0.115 \mathrm{kWh}$ and emissions, which contributed to the circular economy [21]. Cogeneration of energy from forest biomass residues reduced costs and environmental impacts due to increased energy production over biomass use from $0.30 \mathrm{MWh} /$ ton in 2010 to $0.48 \mathrm{MWh} /$ ton in 2019 [2].

Other papers addressed exclusively the environmental assessment of a circular economy in energy cogeneration. The integration of different resources by polygeneration of sweet potato in Chinese agriculture was a solution to improve energy efficiency and reduce greenhouse gas emissions [3]. The use of biomass for energy supply and compost production in an Italian waste manager enabled self-consumption of $10 \%$ of the energy demand of the plant [22]. Anaerobic digestion for energy recovery from sewage sludge in Russian sanitation provided up to $7200 \mathrm{MWh} /$ year of biogas, which reduced greenhouse gas emissions [23]. Energy valorization of waste biomass for cogeneration in the Italian agroforestry sector increased efficiency from 45.8-63.2\%, due to the replacement of diesel generators with a biomass-powered plant, which reduced greenhouse gas emissions [1]. Furthermore, on the use of biomass in cogeneration, the evaluation in Portugal pointed to 97\% cogeneration efficiency, $9 \%$ net electrical efficiency, and 88\% thermal efficiency [24].

In addition, two studies carried out quantitative evaluation on the economic and environmental gains. The use of organic waste from agriculture for biogas generation in China generated revenue from the sale of biogas and reduced costs by $¥ 76,650 /$ year and greenhouse gas emissions by 182 ton $\mathrm{CO}_{2}$ eq per year [25]. The co-generation of energy from 
vegetable oil waste from selective collection favored the circular economy in an Italian waste management company, with economic results of simple payback of 3.4 years, net present value of over $19.0 \mathrm{M} €$, and rate of return of $26.7 \%$, and environmental count with the reduction of $70 \%$ of $\mathrm{CO}_{2}$ eq emissions [26].

Although the cited papers mention cogeneration and a circular economy, there isn't a study that evaluated the environmental and economic gains of energy cogeneration from heat recovery in petroleum refining under a circular economy perspective. The previous papers focused on other activities, such as agriculture, poultry, ecoindustrial parks, manufacturing, waste management, sewage treatment, energy, and forest. Thus, there is a lack of study on this theme in petroleum refining. The gap identified in the literature suggests the following research question: does the heat recovery for energy cogeneration in petroleum refining offer economic and environmental advantages? To obtain the answer to the question raised, this study aimed to evaluate the benefits of the heat recovery for energy cogeneration in the calcination of green petroleum coke.

This study investigated economic and environmental advantages obtained through heat recovery for energy cogeneration. The theoretical foundation was built through a systematic literature review on energy cogeneration and circular economy. The field research was conducted through a case study in a petroleum refinery. The method adopted in the economic evaluation was the discounted payback period, the return on investment, net present value, and internal rate of return. From the environmental perspective, the analysis estimated the reduction of carbon equivalent value due to the implementation of the cogeneration plant.

The motivation of this research is to offer an investigation not yet found in the literature on the economic and environmental advantages of heat recovery for energy cogeneration in petroleum refining. Furthermore, this study intends to encourage industrial managers to seek the adoption of circular economy strategies that use waste as an input, which results in cost saving, additional revenues, and lower environmental impact. Besides the tangible advantages, the circularity of by-products can generate gains to the corporate image through marketing campaigns.

\section{Literature Review}

In this section the content analysis of sixteen studies that addressed the circular economy and the economic and environmental benefits of energy cogeneration is presented.

Five research studies were conducted in the agricultural sector. Zhang et al. [3] developed a case study in China that evaluated energy efficiency and the environmental impact in the life cycle of sweet potato bioethanol production. It was concluded that cogeneration reduced the use of fossil fuels, which decreased toxicity to people due to the reduction of $\mathrm{SO}_{2}, \mathrm{NOx}$, and $\mathrm{CO}_{2}$. This study used a weighted evaluation, in which the environmental impact score was $0.309,0.107$, and 0.082 for conventional production, cogeneration, and circular economy, respectively. The results showed that the option of a circular economy, in which the recycling of cogeneration by-products, such as $\mathrm{CO}_{2}$ and solid waste, sees the least environmental impact.

Gopinath et al. [15] conducted a literature review in which they found that the use of sugarcane bagasse for cleaner energy cogeneration generated additional revenue and reduced waste disposal. Cogeneration promoted industrial symbiosis and circularity of primary and secondary by-products from the sugar industry as a resource source for energy generation and sustainable building materials.

Eggemann et al. [16] presented a case study in Germany in which cogeneration of manure and straw waste by anaerobic digestion of organic feedstocks is a renewable methanol circular economy alternative. Furthermore, sensitivity analysis showed that energy and methane loss parameters of anaerobic digestion in the system influenced the environmental performance.

Chang et al. [25] conducted a case study in Chinese agriculture and cattle ranching in which they found that the recovery of agricultural organic waste for biogas generation, 
a circular economy action, significantly improved resource consumption efficiency and economic gain. The sale of organic vegetables grown with sludge and biogas waste as organic fertilizer generated energy savings of $¥ 76,650$ /year. In environmental terms, biomass energy cogeneration reduced organic fertilizer consumption, air pollution by 182 tonCO $\mathrm{C}_{2} \mathrm{eq}$ per year, and soil pollution through detoxification and recovery of pig excrement.

Baldinelli et al. [21] found in the case study in Italian agribusiness that biogas cogeneration from high-temperature solid oxide fuel cells increased environmental and energy performance, which raised the sustainability level of the business. In addition, energy cogeneration using cattle manure reduced the average cost of electricity from $0.387 \mathrm{kWh}$ to $0.115 \mathrm{kWh}$.

Three energy cogeneration studies were also identified as a circular economy strategy in the forestry sector. Costa et al. [1] presented a case study in Italy on the valorization of waste biomass. The use of process residue as biomass cogeneration input promoted material circularity and added value to the residue, which is a circular economy strategy. The adequacy of the ignition time resulted in a $6 \%$ increase in electricity generation and a reduction of pollutant emissions to levels well below the limits allowed by legislation. Additionally, replacing diesel generators with a biomass-powered plant raised the overall efficiency of the system from 45.8-63.2\%. Torreiro et al. [24] found the energy valorization of agroforestry biomass in a multiple case study in Portugal. The use of biomass from vine, kiwi, heather, gorse, broom, and forest pruning was an alternative waste utilization aimed at the circular economy. The results of this study showed values close to $97 \%$ cogeneration efficiency ( $9 \%$ net electrical efficiency and $88 \%$ thermal efficiency). Simioni et al. [2] identified in an analysis of reports from Brazilian companies that the use of forest biomass residues to generate electricity contributed to the sustainability of the energy matrix, circularity in the forest production chains, cost reduction, and conservation of resources. The increased efficiency of cogeneration raised the energy generated per ton of biomass consumed from $0.30 \mathrm{MWh} /$ ton in 2010 to $0.48 \mathrm{MWh} /$ ton in 2019, in addition to reducing the generation of ash by $55.5 \%$. Eco-efficiency gains were also accounted for in terms of reduced consumption of diesel oil, electricity, and water.

Three other papers mentioned circular economy in energy cogeneration in the industrial sector. Afshari, Farel, and Peng [17] conducted a case study in an eco-industrial park in France, in which they identified solid waste value addition achieved through industrial symbiosis between companies in the eco-park. The potential of cogeneration was considered by managers in replacing energy sources. Cucchiella et al. [20] conducted a multiple case study with simulation that showed opportunity for energy cogeneration in Italian industry using biomethane, which is a renewable energy source that decarbonizes natural gas. The findings of the study showed that the recovery of various wastes for the generation of biomethane increased the circular economy. Economic feasibility was obtained in the cases of $100 \mathrm{~m}^{3} / \mathrm{h}$ organic fraction of municipal solid waste (ofmsw) plant in sensitivity analysis, $50 \mathrm{~m}^{3} / \mathrm{h}$ ofmsw plant in scenario analysis, $150 \mathrm{~m}^{3} / \mathrm{h}$ mixed plant in scenario analysis with a new incentive scheme, and $100 \mathrm{~m}^{3} / \mathrm{h}$ manure waste plant in scenario analysis. Moliner, Marchelli, and Arato [13] conducted a desk review on cogeneration plants for heat and electricity. The study found that the construction of new plants and the modernization of existing units provided significant benefits using value-added by-products that increased the circular economy.

Two studies addressed circular economy and energy cogeneration in waste managers. Novelli et al. [22] identified in the case study at a waste manager in Italy economic gains from biogas and organic compost production and environmental benefits in terms of reduced waste disposal in landfill. The biogas was used in the cogeneration of electricity and heat. Organic compost was sold to the agricultural sector. Thermal energy was partially recovered for heating water in the anaerobic digester. Approximately $10 \%$ of the electricity generated was consumed by the anaerobic digester of the plant and the rest was used to supply the public electricity grid. Di Fraia et al. [26] conducted an experiment on cogeneration of vegetable oil waste from selective collection in a waste management 
company in Italy. The economic analysis indicated a simple payback of 3.44 years, a net present value of over $19.0 \mathrm{M} €$, and a rate of return of $26.7 \%$, which denoted the viability of the business. Besides the economic advantage, the conversion of waste vegetable oil into biodiesel reduced $\mathrm{CO}_{2}$ eq emissions by $70.0 \%$ in relation to fossil fuels.

In an experiment conducted in the poultry industry, Morgano et al. [4] found that the combination of nutrient recycling and energy recovery from chicken manure pyrolysis in an integrated hot gas filtration reactor made the operation self-sustaining in terms of heat and electricity. This study conducted in Germany pointed out that sustainable consumption and by-product recycling increased the circular economy of the operation.

In another experiment at a sewage treatment plant in the Russian sanitation sector, Kiselev et al. [23] concluded that anaerobic digestion is one of the methods of energy recovery from sewage sludge that favors the circular economy. The simulation results showed net energy power of biogas between $6575 \mathrm{MWh}$ /year and $7200 \mathrm{MWh}$ /year, with favorable greenhouse gas balance, i.e., avoided emissions were greater than produced emissions.

Longo, Cellura, and Girardi [19] evaluated environmental aspects of electricity generation from refuse derived fuel in a case study in the power sector in Italy. It was found that solid waste biofuel is an interesting energy option that contributes to the transition from linear to circular economy. The comparative analysis highlighted that electricity from refuse derived fuel performed worse in terms of climate change, human toxicity, and photochemical oxidant formation. On the other hand, electricity from refuse derived fuel performed better than electricity from the public grid and photovoltaics in terms of natural resource depletion, a significant aspect for the circular economy.

The main information of the collected articles is described in Table 1.

Table 1. Articles identified in the systematic literature review on energy cogeneration and circular economy.

\begin{tabular}{|c|c|c|c|c|c|c|c|}
\hline Main Author & Year & Journal & $\begin{array}{l}\text { Research } \\
\text { Method }\end{array}$ & Sector & Country & $\begin{array}{l}\text { Economic } \\
\text { Approach }\end{array}$ & $\begin{array}{c}\text { Environmental } \\
\text { Approach }\end{array}$ \\
\hline Chang, I. & 2011 & $\begin{array}{l}\text { Renewable and } \\
\text { Sustainable } \\
\text { Energy Reviews }\end{array}$ & Case Study & Agriculture & China & $\begin{array}{l}\text { Annual cost saving } \\
\text { of } ¥ 76,650 \text { and } \\
\text { additional revenue } \\
\text { from biogas. }\end{array}$ & $\begin{array}{l}\text { Reduction of } 182 \\
\text { tonCO } \mathrm{CO}_{2} \mathrm{eq} / \text { year. }\end{array}$ \\
\hline Morgano, M.T. & 2017 & $\begin{array}{l}\text { Chemical } \\
\text { engineering } \\
\text { transaction }\end{array}$ & Experiment & Poultry & Alemanha & $\begin{array}{l}\text { The feasibility } \\
\text { depends on the } \\
\text { sales price. }\end{array}$ & $\begin{array}{l}\text { GHG emission } \\
\text { reduction. }\end{array}$ \\
\hline Zhang, J. & 2017 & PLoS ONE & Case Study & Agriculture & China & 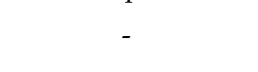 & $\begin{array}{l}\text { GHG emission } \\
\text { reduction. }\end{array}$ \\
\hline Gopinath, A. & 2018 & $\begin{array}{l}\text { Journal of } \\
\text { Cleaner } \\
\text { Production }\end{array}$ & $\begin{array}{l}\text { Literature } \\
\text { Review }\end{array}$ & Agriculture & India & $\begin{array}{l}\text { Additional } \\
\text { revenue. }\end{array}$ & $\begin{array}{l}\text { Use of waste for } \\
\text { power generation } \\
\text { and sustainable } \\
\text { building products. }\end{array}$ \\
\hline Afshari, $\mathrm{H}$. & 2018 & $\begin{array}{c}\text { Resources, } \\
\text { Conservation \& } \\
\text { Recycling }\end{array}$ & Case Study & $\begin{array}{l}\text { Ecoindustrial } \\
\text { parks }\end{array}$ & France & - & $\begin{array}{l}\text { Industrial } \\
\text { symbiosis. }\end{array}$ \\
\hline Cucchiella, F. & 2018 & $\begin{array}{l}\text { Journal of } \\
\text { Cleaner } \\
\text { Production } \\
\text { Environ. }\end{array}$ & $\begin{array}{c}\text { Multiple Case } \\
\text { Studies }\end{array}$ & Manufacturing & Italy & $\begin{array}{l}\text { Economic } \\
\text { feasibility. }\end{array}$ & $\begin{array}{l}\text { Biomethane } \\
\text { generation from } \\
\text { waste recovery. }\end{array}$ \\
\hline Novelli, V. & 2019 & $\begin{array}{c}\text { Engineering and } \\
\text { Management } \\
\text { Journal }\end{array}$ & Case Study & $\begin{array}{c}\text { Waste } \\
\text { management }\end{array}$ & Italy & - & Power generation. \\
\hline Kiselev, A. & 2019 & Resources & $\begin{array}{l}\text { Simulation and } \\
\text { experiment }\end{array}$ & $\begin{array}{l}\text { Sewage } \\
\text { treatment }\end{array}$ & Russian & 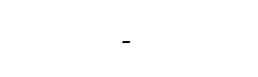 & $\begin{array}{l}\text { GHG emission } \\
\text { reduction. }\end{array}$ \\
\hline Di Fraia, S. & 2020 & $\begin{array}{c}\text { Energy } \\
\text { Conversion and } \\
\text { Management }\end{array}$ & Experiment & $\begin{array}{c}\text { Waste } \\
\text { management }\end{array}$ & Italy & $\begin{array}{c}\text { Payback within } 4 \\
\text { years, net present } \\
\text { value of } 19 \mathrm{M} € \text { and } \\
\text { internal rate of } \\
\text { return of } 26.7 \% .\end{array}$ & $\begin{array}{l}70 \% \mathrm{CO}_{2} \mathrm{eq} \\
\text { emission reduction. }\end{array}$ \\
\hline Moliner, C. & 2020 & Energies & $\begin{array}{l}\text { Documental } \\
\text { analysis }\end{array}$ & $\begin{array}{l}\text { Petrochemical } \\
\text { industry }\end{array}$ & Italy & ( & $\begin{array}{c}\text { Use of waste for } \\
\text { power generation. }\end{array}$ \\
\hline
\end{tabular}


Table 1. Cont.

\begin{tabular}{|c|c|c|c|c|c|c|c|}
\hline Main Author & Year & Journal & $\begin{array}{l}\text { Research } \\
\text { Method }\end{array}$ & Sector & Country & $\begin{array}{l}\text { Economic } \\
\text { Approach }\end{array}$ & $\begin{array}{l}\text { Environmental } \\
\text { Approach }\end{array}$ \\
\hline Eggemann, L. & 2020 & $\begin{array}{l}\text { Journal of } \\
\text { Cleaner } \\
\text { Production }\end{array}$ & Case Study & Agriculture & Germany & $\begin{array}{l}\text { Additional } \\
\text { revenue. }\end{array}$ & $\begin{array}{c}\text { Use of waste for } \\
\text { power generation. }\end{array}$ \\
\hline Longo, S. & 2020 & $\begin{array}{l}\text { Science of the } \\
\text { Total } \\
\text { Environment }\end{array}$ & Case Study & Energy & Italy & - & $\begin{array}{l}\text { Use of waste for } \\
\text { power generation. }\end{array}$ \\
\hline Costa, M. & 2020 & Energies & Case Study & Forest & Italy & - & $\begin{array}{l}\text { Diesel generators } \\
\text { replaced by } \\
\text { biomass unit for } \\
\text { power generation } \\
\text { reduced } 63.2 \% \\
\text { GHG emission. }\end{array}$ \\
\hline Torreiro, Y. & 2020 & Energies & $\begin{array}{c}\text { Multiple Case } \\
\text { Studies }\end{array}$ & Forest & Portugal & 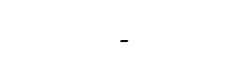 & $\begin{array}{l}97 \% \text { efficiency of } \\
\text { cogeneration. }\end{array}$ \\
\hline Baldinelli, A. & 2021 & $\begin{array}{l}\text { International } \\
\text { Journal of } \\
\text { Hydrogen } \\
\text { Energy }\end{array}$ & Case Study & Agriculture & Italy & $\begin{array}{c}\text { Reduction of } \\
\text { energy } \\
\text { consumption from } \\
\text { 0.387 kWh to } \\
0.115 \mathrm{kWh} .\end{array}$ & $\begin{array}{l}\text { Power generation } \\
\text { and GHG emission } \\
\text { reduction. }\end{array}$ \\
\hline Simioni, F.J. & 2021 & $\begin{array}{c}\text { Clean } \\
\text { Technologies and } \\
\text { Environmental } \\
\text { Policy }\end{array}$ & $\begin{array}{l}\text { Documental } \\
\text { analysis }\end{array}$ & Forest & Brazil & Cost saving. & Power generation. \\
\hline
\end{tabular}

The selected articles have been published in recent years, which denotes circular economy in energy cogeneration as a contemporary theme. Studies on agriculture, poultry, ecoindustrial parks, manufacturing, waste management, sewage treatment, energy, and forest revealed advantages of circular economy strategies in energy cogeneration. The lack of studies on this subject in petroleum refining showed the opportunity to investigate this research area. Based on the results of the mentioned studies, the proposition of this research is: the adoption of a circular economy strategy in energy cogeneration in petroleum refining provides economic gains associated to environmental benefits. The heat recovery of the calcination process, as a circular economy strategy, was the focus of the economic and environmental evaluations.

\section{Materials and Methods}

This research adopts the case study method, which enabled the understanding of the subject in practice to favor the critical analysis of the background theory. Case study has shown significant contributions in the theoretical and practical fields [27] and has proven to be a powerful research methodology in operations management [28]. This research had an exploratory objective and a quantitative approach. The quantitative approach considers numerical data and reference values [29].

In line with the methodological procedures of case study, this work followed the steps defined by Yin [29]. First, the literature review was conducted to understand the theory about the topic of this study. The literature review enabled the identification of the research gap explored in this study. The circular economy approach on energy cogeneration in petroleum refining was a relevant subject for doing a case study. The second step was to design the case study that consisted of developing theory, propositions, and related issues to guide the anticipated case study and generalize its findings. The third step aimed to prepare the gathering of case study evidence. The protocol elaborated in this phase was helpful for delineating the required data from the case. The protocol content concentrated on economic and environmental aspects of the previous process and after the cogeneration unit implementation.

The fourth step consisted of the data collection, which was carried out through observations of production processes and interviews with technicians and managers of the industrial, environmental, and facilities departments. The researchers used a semi-structured 
form as a guide for data collection. Technical reports and semi-structured interviews provided data for carrying out the consistent economic and environmental evaluations. The interviewees presented process details and information that was difficult to be noticed only by observation. The fifth step was the analysis of the results, which in this research consisted of evaluating economic gains and environmental benefits of energy cogeneration from the dissipated heat recovery. The sixth step was to share the findings of this research work by composing a paper that displays enough evidence for the reader to reach their own conclusions. The steps described are illustrated in Figure 1.

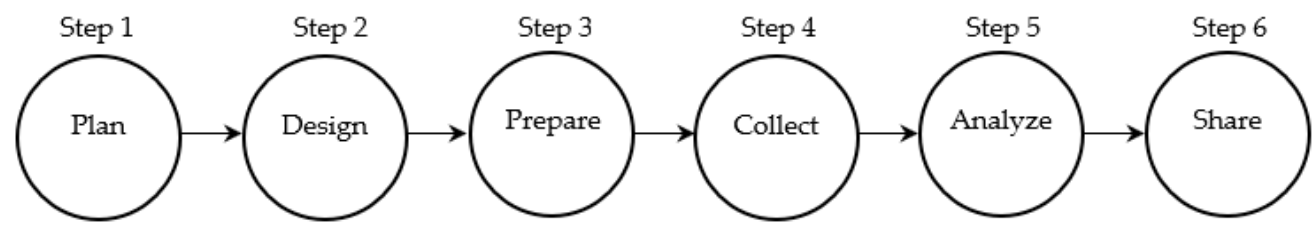

Figure 1. Steps of case study research. Source: Adapted from Yin [29].

The economic assessment of the cogeneration plant were formulated by the methods of discounted payback period (DPBP), return on investment (ROI), net present value (NPV), and internal rate of return (IRR). These methods for assessing economic feasibility have long been applied in business practice, and their procedures are well known and standardized [30]. DPBP indicates the time required to recover the investment by discounting future cash flows and recognizing the time value of money. Specifically, it determines the time taken for an investment to pay for itself. It is estimated by adding up the values of discounted cash flows, period by period, until this sum equals the value of the initial investment. A smaller payback period would be beneficial. ROI and NPV are calculated by Equations (1) and (2) [30]:

$$
\text { ROI }=\frac{\text { Profit after taxes }}{\text { investment }} \times 100
$$

The ROI refers to the ratio of gains to cost and it evaluates in terms of percentage, per period, the rate of return on money invested in the cogeneration plant. A positive ROI indicates that investment gains are greater than the costs. A larger ROI would be beneficial.

$$
\mathrm{NPV}=\sum \frac{R_{\mathrm{t}}}{(1+\mathrm{i})^{\mathrm{t}}}
$$

in which:

$\mathrm{R}_{\mathrm{t}}=$ net cash flows during a single period $\mathrm{t}$

$\mathrm{i}=$ discount or interest rate

The interpretation of a NPV consists of the following: if NPV is positive $(>0)$, the investment in the cogeneration plant will return more than the opportunity cost of funds. If NPV is negative $(<0)$, the project will not return the opportunity cost of funds.

The economic analysis also estimated an IRR that is a discount rate that makes the NPV of all cash flows equal to zero. The IRR value can also be reached by Equation (2). For this purpose, the interest rate (i) is the IRR and NPV is equal to zero in the equation. An electronic sheet is helpful to proceed with the calculation. The SELIC rate is adopted as the minimum rate of return (hurdle rate) in power generation projects [31]. SELIC is the Portuguese abbreviation for Special System for Settlement and Custody. It is the interest rate tax for loans between banks in operations. These operations have government securities as guarantee. The average value of SELIC rate in 2021 was $4 \%$. Thus, assuming that the SELIC rate is the minimum rate of return, the project is economically viable if the estimated IRR is greater than $4 \%$ per year.

The environmental evaluation considered the environmental impacts mitigated due to the implementation of the energy cogeneration unit. Reduction of energy consumption 
and hot exhaust gases emission from the petroleum coke calcination process were the focus of the environmental assessment. The previous condition and after the cogeneration unit implementation are illustrated in Figure 2.

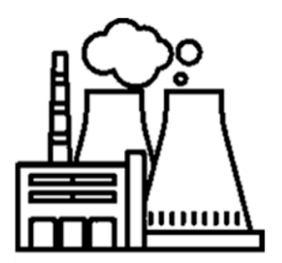

Thermal power plant

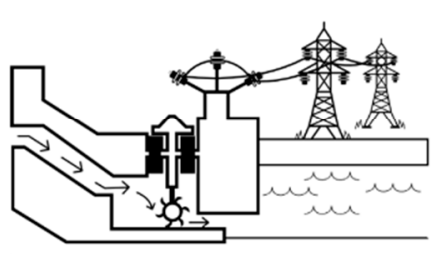

Hydroelectric power plant

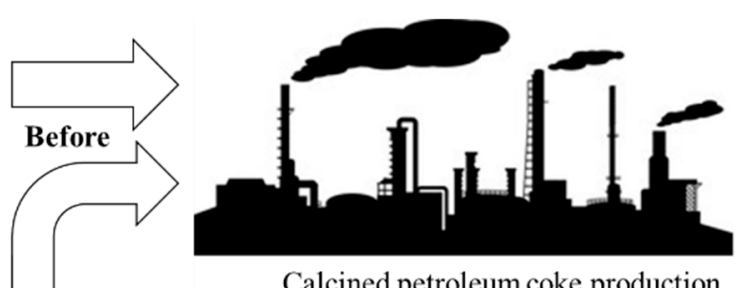

Calcined petroleum coke production

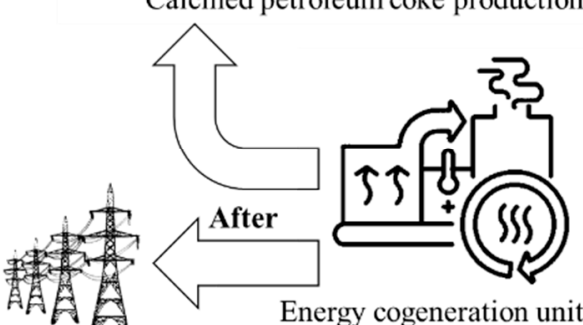

Energy cogeneration unit

THEFORE, there are carbon equivalent reductions by...

(1) reduction in the consumption of electricity generated by hydroelectric and thermoelectric plants
(2) reuse of exhaust gases at high temperatures by the energy cogeneration unit

Figure 2. Process before and after the implementation of the power cogeneration unit.

Electricity generation in southeastern Brazil is concentrated in hydroelectric $(72 \%)$ and thermoelectric $(28 \%)$ plants. The share of other energy sources, such as wind power and photovoltaics, is not significant in the region of the company. The equivalent carbon counting considered the results of Barros et al. [32] that indicated emission of 0.07378 $\mathrm{kgCO}_{2} \mathrm{eq} / \mathrm{kWh}$ for energy generated by hydroelectric plants and $0.38160 \mathrm{kgCO}_{2} \mathrm{eq} / \mathrm{kWh}$ by natural gas-powered thermoelectric. Thus, the $\mathrm{CO}_{2}$ eq avoided after the cogeneration unit implementation was calculated as described in Equation (3).

$$
\mathrm{CO}_{2 \mathrm{eq}}=0.72 \times(0.07378 \times \text { Energy saving })+0.28 \times(0.38160 \times \text { Energy saving })
$$

The process parameters details and the economic and environmental evaluations of the energy cogeneration unit are presented in the next section.

\section{Results}

This case study was conducted in a petrochemical industry located in the Brazilian state of São Paulo. The company has been active for over 40 years in the production of calcined petroleum coke. The calcination process consists of heating green petroleum coke to remove moisture, sulfur, and volatile materials, which increases its purity. Calcined coke is a key product for the aluminum industry, as well as being used as a carbonizer in steel production.

The production runs in a cylindrical furnace that rotates at the rate of two revolutions per minute. The time to transform green coke into calcined coke in the rotary furnace takes about $60 \mathrm{~min}$. The processing rate of green coke was $20.6 \mathrm{~kg} / \mathrm{s}$ by auxiliary firing $0.9 \mathrm{Nm}^{3} / \mathrm{s}$ of natural gas in a rotary furnace at $1250{ }^{\circ} \mathrm{C}$. The exhaust gas temperature was $1100{ }^{\circ} \mathrm{C}$. The calcination process parameters are shown in Figure 3. 


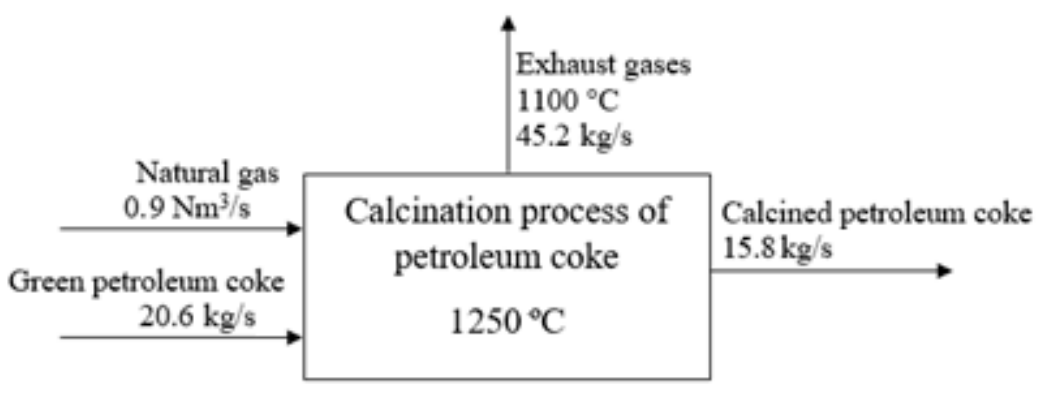

Figure 3. Input and output parameters of the coke calcination process without cogeneration.

The emission of high temperature gases into the atmosphere was an environmental aspect of the operation. The heat recovery of exhaust gases was the factor that motivated the analysis of building a cogeneration unit.

Conventional thermal power plants use a heat source to produce steam that drives the electricity-generating turbine. Following the process, the steam is condensed and returns to the boilers in the liquid state. Despite the use of water working in a closed cycle, there was a significant loss of thermal energy in the condensation stage.

Thermoelectric cogeneration plants use both electrical and thermal energy. These products have commercial value that offers additional revenue for the company. The heat recovery from calcination increased the circularity of resources in petroleum refining. The implementation of the cogeneration unit leveraged the process efficiency. The same number of inputs, $20.6 \mathrm{~kg} / \mathrm{s}$ of green coke and $0.9 \mathrm{Nm}^{3} / \mathrm{s}$ of natural gas, used to produce $15.8 \mathrm{~kg} / \mathrm{s}$ of calcined coke also generates $2.1 \mathrm{kWs}$ of electricity and $2.2 \mathrm{~kg} / \mathrm{s}$ of steam. A synthetic representation of the process parameters with the cogeneration unit is presented in Figure 4.

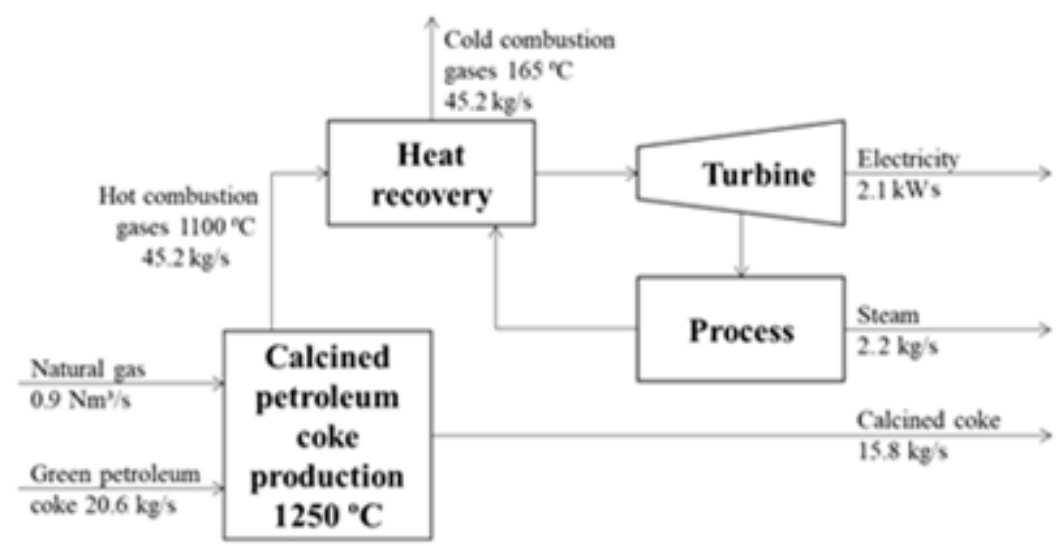

Figure 4. Input and output parameters of the coke calcination and cogeneration processes.

The use of electricity from heat recovery reduced consumption of non-renewable natural resources and emission of toxic gases, compared to fossil fuel power plants.

\subsection{Economic Assessment}

The total investment for the cogeneration unit installation was US\$48.9 million. The operating costs were US\$10.38/MWh, which refer exclusively to the operation and maintenance of the cogeneration plant. This information was obtained in interviews with managers, supported by technical reports.

The electricity produced is traded on the short-term market, according to the availability of generation. Electricity is a co-product, generated from the heat available from the calcination process of green coke. The daily variation of green coke production makes it difficult to guarantee a fixed quantity of electricity supply. This condition is opposite to a conventional thermal power plant, in which electricity generation is tied to a fuel supply 
contract. The risks of failure of electricity supply under a long-term contract have led to the selling of electricity in short-term trading. The prices of electricity on the short-term market are referenced by the settlement price for differences calculated and published weekly by the electric energy commercialization chamber. The average trading value of the electricity generated by the company is US $\$ 118 / \mathrm{MWh}$.

The marketing of steam is also carried out in the short term. However, the supply of steam differs from electricity in terms of distribution infrastructure. The Brazilian electricity grid is composed of an integrated grid that allows the entry of electricity at one point which can be consumed in another very distant point. In the case of steam, long-distance transport would require costs and investment in infrastructure for maintaining a high level of pressure and temperature, which would exceed the energy value of the product. Thus, the supply of steam was restricted to industries near the plant.

The technical-economic restriction of the steam-carrying system also affects consumer industries, which have difficulties in finding steam suppliers. For these industries, the alternative to buying steam from the cogeneration plant is the production of steam itself, by burning fuel, such as liquefied petroleum gas. The price of steam follows the price of liquefied petroleum gas, an energy competitor of the steam produced by the company. To price steam based on the price of liquefied petroleum gas it was necessary to relate the amount of energy contained in the two products.

The steam supply parameters are 2.5 bar and $165^{\circ} \mathrm{C}$. The latent heat to convert liquid water into vapor water is $2501 \mathrm{~kJ} / \mathrm{kg}$ [33]. Liquefied petroleum gas has a calorific value of $11,082 \mathrm{kcal} / \mathrm{kJ}$ [34]. This value is equivalent to $46,378 \mathrm{~kJ} / \mathrm{kg}$, considering that $1 \mathrm{kcal}$ is equivalent to $4185 \mathrm{~kJ}$ [35]. A coefficient for the steam price definition was obtained by dividing the latent heat value of water by the calorific value of liquified petroleum gas. Then, assuming that there are no losses in energy conversions, the coefficient is 0.054 . Thus, the price of steam should be equivalent to 0.054 of the price of liquefied petroleum gas. The price of liquefied petroleum gas in the region is US\$451 per ton, so the price of steam was negotiated between the plant and customers at US\$24.35 per ton.

The prices mentioned for electricity and steam are gross values. The net revenue calculation requires discounting the payment of taxes on the sale of the product, whose rate is $18 \%$, and the social contribution on profits, which is $9 \%$. The feasibility study also considered the depreciation of the investment, which occurs linearly and integrally over the 20-year life of the enterprise. Thus, depreciation occurs at a rate of $5 \%$ per year, with no residual value at the end of 20 years. The weighted average cost of capital was $3.84 \%$ per year. It is the discount rate to estimate net present value and discounted payback period.

The annual supply forecast of cogeneration products was 65,000 MWh of electricity and 54,000 tonnes of steam. The economic evaluation data are presented in Tables 2 and 3.

Table 2. Economic assessment.

\begin{tabular}{lc}
\hline Income Statement (Values in US\$) & Annual Values \\
\hline Electricity saving & $7,670,000$ \\
Steam sales revenue & $1,314,900$ \\
Total additional income (electricity + steam) & $8,984,900$ \\
\hline Operational costs and expenses of cogeneration unit & 674,700 \\
Depreciation & $2,445,000$ \\
Total operational costs and expenses & $3,119,700$ \\
\hline Basis for Income Tax Calculation (electricity + steam) & $5,865,200$ \\
Income tax + social contribution on profit $(27 \%)$ & $-1,583,604$ \\
Profit after taxes & $4,281,596$ \\
Annual profit = profit after taxes + depreciation & $6,726,596$ \\
\hline
\end{tabular}


Table 3. Discounted cash flow.

\begin{tabular}{cccc}
\hline Year & Cash Flow & $\begin{array}{c}\text { Discounted } \\
\text { Cash Flow }\end{array}$ & $\begin{array}{c}\text { Cumulative Discounted } \\
\text { Cash Flow }\end{array}$ \\
\hline 0 & $(48,900,000)$ & $(48,900,000)$ & $(48,900,000)$ \\
1 & $6,726,596$ & $6,477,846$, & $(42,422,153)$ \\
2 & $6,726,596$ & $6,238,296$ & $(36,183,857)$ \\
3 & $6,726,596$ & $6,007,604$ & $(30,176,253)$ \\
4 & $6,726,596$ & $5,785,443$ & $(24,390,809)$ \\
5 & $6,726,596$ & $5,571,497$ & $(18,819,312)$ \\
6 & $6,726,596$ & $5,365,463$ & $(13,453,848)$ \\
7 & $6,726,596$ & $5,167,049$ & $(8,286,799)$ \\
8 & $6,726,596$ & $4,975,971$ & $(3,310,827)$ \\
9 & $6,726,596$ & $4,791,960$ & $1,481,132$ \\
10 & $6,726,596$ & $4,614,753$ & $6,095,886$ \\
11 & $6,726,596$ & $4,444,100$ & $10,539,987$ \\
12 & $6,726,596$ & $4,279,757$ & $14,819,745$ \\
13 & $6,726,596$ & $4,121,492$ & $18,941,237$ \\
14 & $6,726,596$ & $3,969,079$ & $22,910,317$ \\
15 & $6,726,596$ & $3,822,303$ & $26,732,620$ \\
16 & $6,726,596$ & $3,680,954$ & $30,413,575$ \\
17 & $6,726,596$ & $3,544,833$ & $33,958,408$ \\
18 & $6,726,596$ & $3,413,745$ & $37,372,153$ \\
19 & $6,726,596$ & $3,287,505$ & $40,659,658$ \\
20 & $6,726,596$ & $3,165,933$ & $43,825,592$ \\
\hline
\end{tabular}

The estimation of economic values indicated a discounted payback period of eight years and nine months. The NPV of the project was calculated over a span of twenty years with an annual interest rate of $3.84 \%$. Since the NPV shows a positive value of US $\$ 43,825,592$ within a project lifetime, it is suggested that the project is profitable at an interest rate of $3.84 \%$. Based on the discounted cash flow, the cogeneration unit shown ROI estimated to be $14 \%$ and an IRR of $12 \%$. The results showed a positive NPV, high IRR, and small payback, which denotes the cogeneration project is economically viable.

\subsection{Environmental Assessment}

The environmental analysis consisted in measuring the reduction of the environmental impact after the implementation of the energy cogeneration plant. The environmental aspects considered in this analysis were electricity consumption and heat dissipation from the calcination process of green petroleum coke. The estimation of $\mathrm{CO}_{2} \mathrm{eq}$ emission was the method adopted to measure the mitigated environmental impact.

The first step was to consolidate the annual steam and electricity generation data into a common unit of measure, $\mathrm{Wh}$. Thus, the mass of produced steam should be converted into an energy unit. The cogeneration plant capacity was 54,000 tonnes of steam per year. The latent heat to convert liquid water into vapor water is $2501 \mathrm{~kJ} / \mathrm{kg}$. The mass of steam times the latent value resulted in 135,054,000 MJ. This value is equivalent to $135,054,000 \mathrm{MWs}$. In terms of hours, this value is equal to 37,515 MWh. The electricity generation was $65,000 \mathrm{MWh}$. The sum of the produced energy, steam plus electricity, resulted in 102,515 MWh. The energy balance is presented in Table 4. 
Table 4. Energy balance.

\begin{tabular}{lll}
\hline Description & Steam & Electricity \\
\hline Annual generation & 54,000 tonnes & $65,000 \mathrm{MWh}$ \\
Latent value & $2501 \mathrm{~kJ} / \mathrm{kg}$ & \\
Energy & $135,054,000 \mathrm{MJ}$ & \\
& $135,054,000 \mathrm{MWs}$ & $65,000 \mathrm{MWh}$ \\
Total Energy (steam + electricity) & $37,515 \mathrm{MWh}$ & \\
\hline
\end{tabular}

Consistent with the aim of this research, the second step of the environmental assessment was to estimate the advantages of the energy cogeneration unit in terms of $\mathrm{CO}_{2} \mathrm{eq}$ emission. The emission factor defined by Barros et al. [32] was helpful to calculate the reduction of air pollutants. The annual reduction of emissions was found by the sum of the total energy times the emission factor, considering the share of hydro and thermoelectric. The estimation of $\mathrm{CO}_{2}$ eq emission reduction is shown in Table 5.

Table 5. Estimation of carbon dioxide equivalent emission.

\begin{tabular}{lll}
\hline Description & Value & Unit \\
\hline Total Energy (steam + electricity) & $102,515,000$ & $\mathrm{kWh}$ \\
Hydroelectric emission factor & 0.07378 & $\mathrm{kgCO} 2 \mathrm{eq} / \mathrm{kWh}$ \\
Share of hydroelectric in electric matrix & 72 & $\%$ \\
Thermoelectric emission factor & 0.38160 & $\mathrm{kgCO}_{2} \mathrm{eq} / \mathrm{kWh}$ \\
Share of thermoelectric in electric matrix & 28 & $\%$ \\
Annual reduction of emissions & $16,399,283$ & $\mathrm{kgCO}_{2} \mathrm{eq}$ \\
\hline
\end{tabular}

The environmental analysis indicated that the heat recovery for energy cogeneration in petroleum refining reduced 16,399,283 $\mathrm{kgCO}_{2}$ eq per year. Besides reducing the greenhouse gas emission, the heat recovery for producing electricity and steam decreased the exhaust air temperature discharged into the atmosphere from $1100{ }^{\circ} \mathrm{C}$ to $165^{\circ} \mathrm{C}$. It is a benefit for the local ecosystem that was not measured by this study.

\section{Discussion}

The waste elimination in industrial processes is a continuous task in operation management. The high temperature of the exhaust air was identified as a waste in the calcination process. The heat dissipation from the calcination was reused as an input for producing electricity and steam. The results of this study showed that the heat recovery reduced the consumption of electricity from the grid, which resulted in economic advantages for the company and contributed to the preservation of the ecosystem. This finding corroborates the study by Novelli et al. [22] in which the circularity of materials, the use of waste as cogeneration inputs, reduced the demand of the company for grid electricity by $10 \%$.

Another fact was the economic viability of the cogeneration unit project. Economic advantage is the key success factor in the implementation of circular economy strategies. The procedures carried out in this study corroborates the findings of Di Fraia et al. [26], who identified the economic feasibility of energy cogeneration in a waste management company through the payback period. The research of Chang et al. [25] and Baldinelli et al. [21] in agribusiness limited the economic analyses to the survey of cost reduction obtained with the use of energy generated through agricultural organic waste and revenue from the sale of biogas. The findings revealed that this work is the first study that carried out the economic feasibility of energy cogeneration in petroleum refining under the circular economy perspective. Thus, this research adds to the theory by showing economic advantages of heat recovery for power generation in petroleum refining. In addition, there are practical contributions by demonstrating the potential circularity of thermal energy dissipated from the process. 
The environmental assessment indicated that the use of the heat dissipated from the calcination of coke for the cogeneration of electricity and steam reduced 16,399 tonCO $\mathrm{O}_{2}$ eq per year. Carbon dioxide equivalent counting proved to be a suitable method in measuring environmental impact. $\mathrm{CO}_{2} \mathrm{eq}$ is a metric that makes it possible to compare emissions of various greenhouse gases according to global warming potential. The study by Chang et al. [25] used this method to calculate the emission reduction by 182 ton $\mathrm{CO}_{2} \mathrm{eq} /$ year, which was obtained due to the utilization of biogas from agricultural organic waste. Carbon dioxide equivalent counting was also used by Di Fraia et al. [26], who calculated 70\% $\mathrm{CO}_{2} \mathrm{eq}$ reduction due to energy cogeneration from vegetable oil waste from selective collection.

However, other research on energy cogeneration focused on calculating process energy efficiency. The efficiency is measured in percentage terms, which is suitable for monitoring a particular process. However, the comparison of different processes requires an absolute figure in a common unit of measure. In this sense, relative data make it difficult to compare the environmental impact caused in different industries. Costa et al. [1] pointed out the increase in energy efficiency from $45.8-63.2 \%$ due to the replacement of the diesel generator set with a biomass-powered plant. Torreiro et al. [24] measured 97\% cogeneration efficiency ( $9 \%$ net electrical efficiency and $88 \%$ thermal efficiency) with the energy valorization of agroforestry biomass.

The originality of this study was to estimate the reduction of greenhouse gas emissions, in terms of carbon equivalent, of energy cogeneration in petroleum refining. This result contributed to the theory by confirming that the environmental costs do not compromise investment convenience. In addition, there are practical contributions by demonstrating through the estimations carried out in this study that the investment in circular economy strategies was profitable from an economic and environmental point of view.

\section{Conclusions}

This work achieved its objective of evaluating advantages of energy cogeneration in petroleum refining under a circular economy perspective. The heat recovery for energy cogeneration is a circular economy strategy designed to benefit businesses, society, and the environment. The use of waste as an input of other processes promoted the industrial symbiosis, increased revenues and cost saving, and mitigated environmental impact. These advantages show that the circularity of resources should be part of the corporate strategic planning to maintain competitiveness and business survival.

The carbon equivalent counting allowed us to estimate the environmental impact in terms of reduction of greenhouse gas emissions. Although this method is simple to manage, it was little adopted in articles on cogeneration and circular economy. From an economic perspective, the return on investment, discounted payback period, net present value, and internal rate of return carried out by this study provided information used in business decision making. The figures revealed the viability of the cogeneration unit project. Most of the papers identified in the literature on cogeneration and circular economy focused on cost saving as the main parameter of economic analysis.

The theoretical contribution of this research was to provide a work not yet detailed in the scientific literature on energy cogeneration in petroleum refining under a circular economy point of view. Circular economy as a contemporary concept toward sustainable development should be extended to economic activity sectors. This finding shows the opportunity for future research to investigate the use of circular economy strategies in sectors not yet exploited.

As a contribution to corporate practice, this study intends to encourage industrial managers to plan actions to eliminate waste through the adoption of strategies to circulate products and materials at their highest value. Environmental advantages associated with economic gains can stimulate changes at the current linear economy embedded in several organization processes. Alternatives aimed at promoting the circularity of by-products in their processes or in an industrial symbiosis chain contributes to regenerate the environment by moving from a take-make-waste linear economy to a circular economy in which the 
society and ecosystem grow and thrive together. Moreover, circular economy practices add value to the corporate image.

The contribution to society is highlighted by the fact that the company has reduced the consumption of electricity from the public grid, which increased the availability of this resource to the population and reduced the risk of blackouts. In addition, the energy cogeneration reduced the need for conventional thermoelectric power plants, which are a source of pollution.

The exploratory purpose of this research limited its finding to the firm focused on in the study. The method and data collected do not allow the generalization of the results. Another limitation of this study is the focus on the heat recovery. Other types of waste are embedded in operational processes of petroleum refining. In this sense, future studies should explore the use of circular economy strategies in petroleum refining under different perspectives. Moreover, more deep knowledge about social factors should be addressed to studies on circular economy and energy cogeneration.

Author Contributions: Conceptualization, H.N.P.T. and G.C.d.O.N.; methodology, H.N.P.T. and G.C.d.O.N.; formal analysis, L.F.R.P., G.M. and F.F.; investigation, L.F.R.P. and H.N.P.T.; resources, G.M. and F.F.; writing — original draft preparation, L.F.R.P. and H.N.P.T.; writing — review and editing, G.C.d.O.N.; visualization, G.M. and F.F.; supervision, G.C.d.O.N.; project administration, G.C.d.O.N. and G.M. All authors have read and agreed to the published version of the manuscript.

Funding: This research received no external funding.

Institutional Review Board Statement: Not applicable.

Informed Consent Statement: Not applicable.

Data Availability Statement: The study did not report any data.

Conflicts of Interest: The authors declare no conflict of interest.

\section{References}

1. Costa, M.; Buono, A.; Caputo, C.; Carotenuto, A.; Cirillo, D.; Costagliola, M.A.; Di Blasio, G.; La Villetta, M.; Macaluso, A.; Martoriello, G.; et al. The "INNOVARE" Project: Innovative Plants for Distributed Poly-Generation by Residual Biomass. Energies 2020, 13, 4020. [CrossRef]

2. Simioni, F.J.; Jarenkow, G.L.; da Silva, K.F.; Brutti, R.C.; Junior, L.M.C. Eco-efficiency in the transformation of forest biomass residues in electrical energy. Clean Technol. Environ. Policy 2021, 23, 1443-1456. [CrossRef]

3. Zhang, J.; Jia, C.; Wu, Y.; Xia, X.; Xi, B.; Wang, L.; Zhai, Y. Life cycle energy efficiency and environmental impact assessment of bioethanol production from sweet potato based on different production modes. PLoS ONE 2017, 12, e0180685. [CrossRef] [PubMed]

4. Morgano, M.T.; Bergfeldt, B.; Leibold, H.; Richter, F.; Stapf, D. Intermediate Pyrolysis of Agricultural Waste: A Decentral Approach towards Circular Economy. Chem. Eng. Trans. 2018, 65, 1-7. [CrossRef]

5. Petković, B.; Zandi, Y.; Agdas, A.S.; Nikolić, I.; Denić, N.; Kojić, N.; Selmi, A.; Issakhov, A.; Milošević, S.; Khan, A. Adaptive neuro fuzzy evaluation of energy and non-energy material productivity impact on sustainable development based on circular economy and gross domestic product. Bus. Strat. Environ. 2021, 31, 129-144. [CrossRef]

6. Esteva, L.C.A.; Kasliwal, A.; Kinzler, M.S.; Kim, H.C.; Keoleian, G.A. Circular economy framework for automobiles: Closing energy and material loops. J. Ind. Ecol. 2020, 25, 877-889. [CrossRef]

7. Chen, W.-M.; Kim, H. Circular economy and energy transition: A nexus focusing on the non-energy use of fuels. Energy Environ. 2019, 30, 586-600. [CrossRef]

8. Castro Oliveira, J.; Lopes, J.M.; Farinha, L.; Silva, S.; Luízio, M. Orchestrating entrepreneurial ecosystems in circular economy: The new paradigm of sustainable competitiveness. Manag. Environ. Qual. 2021, 33, 103-123. [CrossRef]

9. Zhao, F.; Fan, Y.; Zhang, S. Assessment of efficiency improvement and emission mitigation potentials in China's petroleum refining industry. J. Clean. Prod. 2021, 280, 124482. [CrossRef]

10. $\mathrm{Li}$, Y.; Wang, B.; Xie, Y.; Zhu, L. Cost and potential for $\mathrm{CO}_{2}$ emissions reduction in China's petroleum refining sector-A bottom up analysis. Energy Rep. 2020, 6, 497-506. [CrossRef]

11. Morales, M.; González-García, S.; Aroca, G.; Moreira, M.T. Life cycle assessment of gasoline production and use in Chile. Sci. Total Environ. 2015, 505, 833-843. [CrossRef] [PubMed]

12. Liu, Y.; Lu, S.; Yan, X.; Gao, S.; Cui, X.; Cui, Z. Life cycle assessment of petroleum refining process: A case study in China. J. Clean. Prod. 2020, 256, 120422. [CrossRef] 
13. Hamadeh, H.; Toor, S.Y.; Douglas, P.L.; Sarathy, S.M.; Dibble, R.W.; Croiset, E. Techno-Economic Analysis of Pressurized Oxy-Fuel Combustion of Petroleum Coke. Energies 2020, 13, 3463. [CrossRef]

14. Su, C.; Urban, F. Circular economy for clean energy transitions: A new opportunity under the COVID-19 pandemic. Appl. Energy 2021, 289, 116666. [CrossRef]

15. Gopinath, A.; Bahurudeen, A.; Appari, S.; Nanthagopalan, P. A circular framework for the valorisation of sugar industry wastes: Review on the industrial symbiosis between sugar, construction and energy industries. J. Clean. Prod. 2018, 203, 89-108. [CrossRef]

16. Eggemann, L.; Escobar, N.; Peters, R.; Burauel, P.; Stolten, D. Life cycle assessment of a small-scale methanol production system: A Power-to-Fuel strategy for biogas plants. J. Clean. Prod. 2020, 271, 122476. [CrossRef]

17. Afshari, H.; Farel, R.; Peng, Q. Challenges of value creation in Eco-Industrial Parks (EIPs): A stakeholder perspective for optimizing energy exchanges. Resour. Conserv. Recycl. 2018, 139, 315-325. [CrossRef]

18. Moliner, C.; Marchelli, F.; Arato, E. Current Status of Energy Production from Solid Biomass in North-West Italy. Energies 2020, 13, 4390. [CrossRef]

19. Longo, S.; Cellura, M.; Girardi, P. Life Cycle Assessment of electricity production from refuse derived fuel: A case study in Italy. Sci. Total Environ. 2020, 738, 139719. [CrossRef]

20. Cucchiella, F.; D'Adamo, I.; Gastaldi, M.; Miliacca, M. A profitability analysis of small-scale plants for biomethane injection into the gas grid. J. Clean. Prod. 2018, 184, 179-187. [CrossRef]

21. Baldinelli, A.; Barelli, L.; Bidini, G.; Cinti, G. Micro-cogeneration based on solid oxide fuel cells: Market opportunities in the agriculture/livestock sector. Int. J. Hydrogen Energy 2021, 46, 10036-10048. [CrossRef]

22. Novelli, V.; Geatti, P.; Ceccon, L.; Gratton, S. Biomass exploitation for energy supply and quality compost production. an exemplary case of circular economy in the north east of Italy. Environ. Eng. Manag. J. 2019, 18, 2163-2169.

23. Kiselev, A.; Magaril, E.; Magaril, R.; Panepinto, D.; Ravina, M.; Zanetti, M.C. Towards Circular Economy: Evaluation of Sewage Sludge Biogas Solutions. Resources 2019, 8, 91. [CrossRef]

24. Torreiro, Y.; Pérez, L.; Piñeiro, G.; Pedras, F.; Rodríguez-Abalde, A. The Role of Energy Valuation of Agroforestry Biomass on the Circular Economy. Energies 2020, 13, 2516. [CrossRef]

25. Chang, I.-S.; Zhao, J.; Yin, X.; Wu, J.; Jia, Z.; Wang, L. Comprehensive utilizations of biogas in Inner Mongolia, China. Renew. Sustain. Energy Rev. 2011, 15, 1442-1453. [CrossRef]

26. Di Fraia, S.; Massarotti, N.; Prati, M.V.; Vanoli, L. A new example of circular economy: Waste vegetable oil for cogeneration in wastewater treatment plants. Energy Convers. Manag. 2020, 211, 112763. [CrossRef]

27. Barratt, M.; Choi, T.Y.; Li, M. Qualitative case studies in operations management: Trends, research outcomes, and future research implications. J. Oper. Manag. 2011, 29, 329-342. [CrossRef]

28. Voss, C.; Tsikriktsis, N.; Frohlich, M. Case research in operations management. Int. J. Oper. Prod. Manag. 2002, 22, 195-219. [CrossRef]

29. Yin, R.K. Case Study Research: Design and Methods, 4th ed.; Sage: Newbury Park, CA, USA, 2009.

30. Meramo-Hurtado, S.I.; González-Delgado, Á.; Rehmann, L.; Quinones-Bolanos, E.; Mehvar, M. Comparative analysis of biorefinery designs based on acetone-butanol-ethanol fermentation under exergetic, techno-economic, and sensitivity analyses towards a sustainability perspective. J. Clean. Prod. 2021, 298, 126761. [CrossRef]

31. AAlcantara, S.C.S.; Ochoa, A.A.V.; Costa, J.A.P.; Michima, P.S.A.; Silva, H.C.N. Natural gas based trigeneration system proposal to an ice cream factory: Na energetic and economic assessment. Energy Convers. Manag. 2019, 197, 111860. [CrossRef]

32. Barros, M.V.; Piekarski, C.M.; De Francisco, A.C. Carbon Footprint of Electricity Generation in Brazil: An Analysis of the 2016-2026 Period. Energies 2018, 11, 1412. [CrossRef]

33. Shao, X.; Pu, L.; Tang, X.; Yang, S.; Lei, G.; Li, Y. Parametric influence study of cryogenic hydrogen dispersion on theoretical aspect. Int. J. Hydrogen Energy 2020, 45, 20153-20162. [CrossRef]

34. Delgado-Plaza, E.; Quilambaqui, M.; Peralta-Jaramillo, J.; Apolo, H.; Velázquez-Martí, B. Estimation of the Energy Consumption of the Rice and Corn Drying Process in the Equatorial Zone. Appl. Sci. 2020, 10, 7497. [CrossRef]

35. Mueller, E.F.; Rossini, F.D. The Calory and the Joule in Thermodynamics and Thermochemistry. Am. J. Phys. 1944, 12, 1-7. [CrossRef] 